\title{
INKLUSIVISME ISLAM DALAM MEMAHAMI FENOMENA KEMANUSIAAN
}

\author{
Oleb : Abmad Barizi
}

$\mathbf{S}$ alah sattu perdebatan dalam sosiologi agama, yang mencoba memahami agama sebagai realitas sosial, yang tampaknya sampai kini masih berlanjut, ialah bagaimana agama itu clihadapai dan clikaji secara akademis. Artinya, agama merupakan hal yang sangat penting bagi para pemeluknyal yang dengan mudah dapat diketahui clan bisal juga dilihat. Mesjicl yang semakin megah, keberbagaian partai agama (terutana Islam) yang kian menguak akibat retasnya era reformasi, yang páda gilirannya ditandai dengan pluraritas simbolisme keagamaan masyarakat, ini merupakan wujud luar yang mudah kelihatan dan tampaknya tak perlu diperdebatkan. Dalam sejarahpun berbagai peristiwal yang melibatkan agama yang selalu direkam, baik dalam ingatan kolektif yang dipelihara oleh traclisi lisan komunitas pemeluk agama, maupun clalam catatan yang berserakan, clalam arsip, clalam

Apakah agamahanya harus
dilihat dalam studi yang
bercorak historis-empirik
atau dalam batas batas
tertentu berada pada wilayah
normatif-transendental ? Atau
agama, khususnya Islam,
ajaran-ajarannya merupakan
akumulasi dialektis kedua
perspektif tersebut?
kisah kepahlawanan, syair pujalan clan sebagainya!. Sedemikian banyaknya peristiwa keagamaan terjadi, sehingga bisal juga timbul pertanyalan yang hampir tak terjawab, meskipun bisal sajal tercatat. Telah berapal kalikah calam sejarah, baik clalam sejarah nasional maupun sejarah lokal, agama -sebagaimana dipahami dan dikatakan para pendukungnyal- tampil sebagai landasian ideologi, etis, moral, way of life, atau alasian untuk berbuat apal sajja -baik yang berkaitan dengan ritual individual, kerja sosial, maupun perang kesukuan?

Berbagai peristiwa sejarah yang melibatkan agama kiranya menggugah para pemeluk clan pemerhati untuk senantiasa respek dalam meresponnya. Para ahli politik misalnyal, mungkin dan tentu bisá berkata bahwa kalau sekiranya agama telah dipakai calam kancaln persaingan politik, maka pada akhirnya bukan tak mungkin akan berhadapan clengan apa yang kita kenal dengan kebarusan yang tidak bisa dirundingkan. Bukankalh agama memberi batasán yang jelas, antara yang bisă dirundingkan katakaln sajja yang bistoris-empiris-kontekstual-dengan sesuatu yang kita sebut absolut-normatif-dogmatis yang harus diterima sebagaimana yang clitentukan. Sementara ahli sejarah mungkin bisa berkisah kesanaan agama sebagai landasan integrasi sosial yang paling ampuh. Dan, pada salat yang sama, sejarawan clapat pula bertutur, bahwa ada kalanya agama tampil sebagai faktor disintegratif yang tak kurang handalnya. Dan suclah tentu seorang sastrarawan pun clapat bertutur tentang betapa kesyahduan transendental yang dihayati oleh penyair yang telah menghasilkan karya sastra yang tak jarang dianggap sebagai karya monumental. Tetapi, apakah agama hanya harus dilihat clalam stucli yang bercorak historis-empirik attau dalam batas-batas tertentu berada palda wilayah normatif-transendental ? Atau agama, khususnya Islam, ajaran-ajarannya merupakan akumulasi clialektis kedua perspektif tersebut?

\section{Konsepsi Studi Agama : Sebuah Orientasi Dialektis}

Prof.Dr. Azyumardi Azra melihat bahwa dalam wacana studi agama kontemporer, secara garis besar 
terdapat dua bentuk penclekatan, teologi clan pendekatan sejarah². Pendekatan kajian teologi, yang pada a walnya bersumber clari tradisi agama Kristen di Eropa, menyodorkanpemabaman normatif mengenai sebuah agama. Dimana kajian-kajian terhadap sebuah agama akan selalu diukur clari kesesuaiannya dengan dan manfaatnya bagi keimanan. Sedangkan pendekatan sejarah agama berangkat dari pemahaman tentang fenomena historis clan empiris, sebagai manifestasi clan pengalaman masyarakat agama. Dimana bentuk pendekatan kedua ini tidak atau kurang mempertimbangkan klaimklaim keimanan clan kebenaran, sebagaimana dihayati para pemeluk agama itu sencliri.

Kasus Barat misalnya, Azyumardi Azra mengungkap bahwa kajian teologi yang normatif mengalami marjinalisasi dan ditinggalkan oleh pemerhati karena kurang memberikan gairah intelektual yang spesifik simplistik dalam memahami fenomena keagamaan. Sebab dalam penclekatan ini cenclerung mengartikulasikan agama. sebagai sistem-sistem teologi, hukum dan ibadah yang sempit. Agama hanya dipahami sebagai rentetan wahyu yang absolut dari cleretan teks yang terakumulasi dalam sebuah kitab suci(Al-Qur'an). Padahal kalau kita mau jujur, menurut Mohammed Arkoun, deretan teks clalam kitab suci (Al Qur'an) tak lebih hanyalah "alat" untuk membangun teks-teks lain yang clapat memenuhi kebutuhan dan selera masyarakat suatu masa tertentu ${ }^{3}$. Artinya, dalam perspektif bahasa hukum, bukan hanya sesuatu yang tidak ada referensinya di dalam Al-Qur'an yang memerlukan penafsiran (ijtihad), tetapi terhadap Al-Qur'an sencliri kita perlu mengadakan ijtihad (kritik). Sementara penclekatan kedua, di Barat, menemukan momentumnya yang kuat yang berorientasi kepada tradisi keagamaan yang hidup, yang historis, ketimbang "kumpulan tatanan doktrin" yang terangkum clalam Al-Qur'an clan Hadist, sebagaimana pendekatan pertama.

Sejalan denagn tipologi pendekatan studi diatas adalah Dr.Amin Abdullah mencoba memberikan analisa yang serupa tentang penclekatan studi agama, antara normativitas clan historisitasi. Anin berasumsi bahwa pemikiran clan peraclaban suatu agama tak lain aclalah hasil akumulasi perjalanan clan pergumulan penganut agama ketika berhadapan clengan "proses clialektis" antara normativitas ajaran wahyu yang permanen dan bistorisitas pengalaman kekhalifahan manusia climuka bumi yang selalu berubahubah". Menurutnya, keclua dimensi inilah yangselalu terjadi tarik menarik dalam memberikan corak dan warna sejarah pemikiran studi ägama. Artinya, keclua dimensi ini kadang berjalan secara pararel seirama clan kaclang mengalami tension atau ketegangan, baik yang bersifat kreatif maupun destruktif.

Analisa clan interpretasi Amin Abdullah mengenai hal tersebut sebenarnya bukanlah sesuatu yang baru dalam studi Agama. Tinjauan analitis clan interpretatif Amin Abdullah, menurut hemat penulis, merupakan perpanjangan kategori Islam oleh Fazlur Rahman, antara Islam normatif dan historis ${ }^{6}$. Meskipun kita perlu mengakui secara arif bahwa bahwa tulisan Amin Abdullah tentang studi Agama antara normativitas atau historisitas tersebut kiranya menemukan sifatnya yang praktis-kontekstual untuk cliaktualisasikan dalam 
kesejarahan manusia daripada tulisan fazlur Rahman yang menurut penulis masih bersifat konseptualiclealis? Ini bisa climengerti dari mainstream analisa Amin Abclullah yang ingin mengembalikan agama pada rational spirit-nya yang inklusif yang tampil clengan tawaran-tawaran kultural yang procluktif dan konstruktif, serta mampu menyatakan cliri sebagai pembawa kebaikan untuk semua, tanpa eksklusivisme komunal. Kontruksi pemikiran ini sesungguhnya ingin melahirkan pemikiran yang semula bercorak reosentris-lektualis ke arab antroposentrisfenomenologis, yaitu sesuatu pendekatan yang mencari keseimbangan antara "kesalehan individual" clan "kesalehan sosial clan struktural". Karena itu, maka pemikiran keagamaan clan keislaman dalam setiap pergantian paket sejarah akan banyak mengalami modifikasi, deviasi, adaptasi clan reinterpretasi clari keIslaman yang berkembang di Timur Tengah"s. Hal ini merupakan sesuatu yang absah bila clilihat dari perspektif buclaya, sebab Islam tanpa gerak kebuclayaan hanya akan menjacli tontonan artifisial yang membosankan. Sekalipun di satu sisi, ia harus mengalami proses reduksi untuk menemukan kesesuaian clan keseimbangan clalam realitas sosial yang majemuk sebagai fenomena manusiawi (sunnaiullab) yang tak terbantahkan.

\section{Islam Inklusif : Sebuah Artikulasi Fenomena Manusiawi}

Konsistensi sebagian intelektual clan "fungsionaris agama" (old intellectual) tentang adanya suatu yang abstrak clan yang kongkret clalam suatu agama atau fenomena agama, atau dengan perkataan yang tak jauh berbeda adalah bahwa adanya sesuatu yang transenden dan yang empiris, nampaknya sampai di penghujung terminal abad 20 ini tidak bisa di-nafikan dari ingatan kolektif umat Islam. Hal ini clapat dimengerti clari statemen ajaran agama yang menyatakan bahwa agama berasal dari Tuhan, yang bersifat mutlak clan immaterial. Konsistensi ini mengundang pertanyaan yang selalu muncul ke permukaan, yaitu mungkinkah manusia yang mate- rial ini akan mampu menangkap pesan Tuhan yang immaterial itu secara utuh clan sempurna? Atau seperti apa yang di tulis Muhaimin, bagaimana manusia bisa memahami ide Tuhan yang tertuang dalam teks nash clengan benar, sementara manusia ticlak mampu berhadapan langsung dengan-Nya (the word of the Autbor) untuk menanyakan secara langsung apa yang clikehenclaki-Nya". Karena itu, pemahaman kita tentang suatu "makna" keberagamaan, clemikian analisa Muhaimin, berada clalam teks (the word of the text), dalam otak pengarang (the word of the autbor) clan clalam benak pembacanya (the word of the readers). Ketiga-tiganya merupakan titik pusaran yang saling menclukung atau bisa jadi "membelokkan" dalam memahami sebuah teks.

Namun demikian, apapun yang diungkapkan oleh teks kitab suci tentang icle Tuhan hanya mampu dipahami oleh manusia sebagai ungkapan-ungkapan analogis dengan alam pikiran dan dunia empiris manusia. Karena pernyataan tentang Tuhan ticlak bisa diverifikasi atau difalsivikasi secara obyektif dan empiris, maka clalam memahami teks kitab suci seseorang cenclerung menggunakan standar ganda. Yaitu, seseorang berpikir clalam kapasitas clan berclasarkan pengalaman kemanusiaan namun diarahkan untuk suatu obyek yang diimani yang berada di luar jangkauan nalar dan inderanya. Inilah yang kita kenal calam ilmu kalam dengan istilah "nalar yang beriman" atau "iman yang bernalar"to. Artinya penalaran tentang firman Tuhan clalam rangka melayani iman atau beriman pada Tuhan berdasarkan pertimbangan logis.

Pengakuan akan eksistensinya kemahamutlakan Tuhan yang tidak bisa cliverifikasi secara material oleh manusia di atas mengandung "pengertian" bahwa Is= lam aclalah agama yang eksklusif. Eksklusivisme Islam ini akan terasa lebih jelas manakala doktrin tawbid denagn clua kalimah syahadat diklaim sebagai bentuk kesaksian yang tak boleh didiskusikan atau diclialogkan. Dan orang-orang yang mencoba untuk mendiskusikan dan mendialogkan doktrin itu akan selalu cliasosiasikan sebagai perbuatan "syirk". 
(associationsm)karena mereka dianggap telah melakukan pengasosiasian terhadap Tuhan Yang Maha Mutlak dengan "tuhan-tuhan palsu" (pseudo-gods).

Tetapi perlu dicatat, ketika sebuah agama yang bersumberkan kepada wahyu Tühan tersebut sudah termanifestasi dalam bentuk bahasa manusia -katakan clisini bahasa Arab untuk Islam yang sangat lokal dan kondisional-,maka pendekatan budaya dalam memahami bahasa Tuhan tersebut adalah sesuatu yang urgen. Artinya, fenomena manusiawi kiranya ikut mewarnai bagi terbentuknya teks suci (Al-Qur'an) yang itu diyakini sebagai wahyu Tuhan. Pernyataan ini akan menjadi logis kalau kita mau membaca sejarah turunnya ayat-ayat Al-Qur'an (asbab 'I-nuzul) secara berangsur-angsur. Dua kata dalam kurung itu, di satu sisi berada pada wilayah insaniyat (baca:kata "asbab", yang berarti hukum kausalitas yang bersifat fenomenologis dan empiris milik manusia) dan ada pada wilayah ilabiyat disisi yang lain (baca: kata "nuzul", yang berarti turun yang bersifat vertikaltransendental milik Tuhan). Dengan ini dapat disimpulkan bahwa wahyu Tuhan yang sudah terangkum dalam sebuah teks suci (Al-Qur'an) merupakan suatu "respon" terhadap wilayah manusia yang sangat fenomenologis-antropologis clan empiris.

Dengan demikian, Islam tidak hanya memberikan penekanan eksklusif seperti diungkapkan di atas, melainkan juga memberikan penekanan khusus pada inklusivisme keagamaan, sebagaimana bisa disimak dari sejumlah ajaran Al-Qur'an dan
Sunnah yang menempatkan manusia sebagai "pusaran" dari perhatiannya. Maka tidak salah bila pandangan Al-Qur'an tentang posisi manusia dihadapan jagat raya ini oleh kalangan fisikawan modern diistilahkan sebagai antbropic principle ${ }^{11}$. Yaitu, satu pandangan bahwa manusia adalah pusat kehidupan dan pengguna jasa dari mahluk serta benda-benda yang berada disekitarnya.

Karena manusia sebagai sentral bagi terbentuknya ajaran Islam inilah menuntut terciptanya inklusivisme keagamaan manusia di muka bumi. Konsepsi inklusivisme keagamaan ini akan tercipta dalam peradaban manusia secara dinamis dan harmonis bila kesadaran pesaudaraan manusia secara universal (universal brotherbood) sudah terbentuk. Seperti kesadaran akan hak asasi manusia, hak menikmati kehidupan, hak kebebasan beragama dan tidak beragama ${ }^{12}$, hak menikmati anugerah alam seterusnya. Sebab Islam pada esensinya memandang manusia dan kemanusiaan secara sangat positif dan optimistis ${ }^{13}$. Sementara perbedaaan dan distingsi manusia hanyalah sebagai life testing untuk menentukan kadar ketaqwaannya.

Terakhir, konsepsi inklusivisme Islam di atas kiranya sebagai artikulasi teerhadap fenomenafenomena manusiawi yang sangat pluraldan majemuk, yang pada esensinya diharapkan ditemukannya konsep tentang "kesatuan umat manusia" (universal bumanity, ummatan wahidah). 
${ }^{1}$ Tentang keterkaitan agama dengan berbagai realitas budaya manusia sebagai suatu kemestian dapat dilihat misalnya Aswab Mahasin dkk.(ed.), Rub Islam dalam Budaya Bangsa : Aneka Budaya Nusantara, Yayasan Istiqlal Jakarta 1996

2 Prof.Dr.Azyumardi Azra, Studi Islam di Timur dan Barat: Pengalaman Selintas, UQ.No.3,vol.V, TH.1994, bal. 4

${ }^{3}$ Lihat Mohammed Arkoun, Metode Kritik Akal Islam, UQ. No.5\&6, vol.V TH. 1994, hal. 157

' Lihat Dr. Amin Abdullah, Studi agama: Normat ivitas atau Historitas?, Pustaka Pelajar, Yogyakarta 1996 ____ Falsafah Kalam di Era Postmodernisme, Pustaka Pelajar, Yogyakarta 1995, hal.3

6. Seperti yang ditulis M. Dawam rahardjo, Islam menurut Fazlur Rahman ada dua, yaitu Islam Normatif dan Islam Historis. Kategori ini dapat pula kita bandingkan dengan pendapatnya Bernard Lewis, seorang orientalis, ahli sejarah Islam terkemuka, yang membagi Islam ke dalam tiga hal yang berbeda. pertama Islam sebagai agama yang tertulis dalam Al-Qur'an, yang dipercayai oleh kaum Muslimin sebagai wahu Allah. kedua. Islam sebagai teologi. Ini merupakan interprestasi terhadap Al-Qur'an dan Hadits, baik yang sifatnya tekstual maupun kontekstual. dan ketiga Islam sebagai yang telah diwujudkan dalam berbagai bentuk peradaban. Dalam hal ini Fazlur Rahman, menurut Dawam lebih menekankan pada Islam yang kedua, Yaitu Islam sebagai teologi. Lihat M.Dawam Rahardjo, Intelektual Intelegensia dan Perilaku Politik bangsa : Risalab Cendikiawan Muslim, Mizan-Bandung 1993, hal.257

${ }^{7}$ Lihat misalnya Konsepsi Islam menurut Fazlur Rahman dalam bukunya, Islam, terj. Ahsin Mohammad, Pustaka Salman ITB-Bandung 1984
${ }^{8}$ Komaruddin Hidayat, Pembaruan Islam : Dari Dekonstruksi ke Rekonstruksi, UQ.NO.3, Vol. VI, TH. 1995, hal.3

${ }^{9}$ Muhaimin, Pemikiran Modern dalam Islam : Implikasinya Terbadap Studi di STAIN Malang, Majalah el-Harakah No. 5/XVII/Pebruari-April 1999, hal. 18

${ }^{10}$ Komaruddin Hidayat, Memabami Babasa Agama : Sebuab Kajian Hermeneutik, Paramadina, Jakarta 1996, hal.6-8. Uraian lebih lanjut lihat Ronald E. Santoni (ed.), Religious Language and The Problem of Religious Knowledge, (london : Indiana Univercity press,1968); Robert P.Scharlemann dan Gilbert E.M. Ogutu (ed.), God in Languge,, Paragon House, 1987) Robert P. Scharlemenn, Naming God, (Paragon House, 1985)

${ }^{11}$ Dr.Komaruddin Hidayat, Tragedi Raja Midas : Moralitas Agama dan Krisis Modernisme, Paramadina, Jakarta 1998, hal 76

12 Dalam perspektif Al-Qur'an, Islam dengan tegas memberikan kebebasan sepenuhnya kepada manusia dalam masalah agama dan keberagamaan (lihat : QS.Al-Baqarah : 156; QS.Al-Kahfi : 29; dan QS.Yunus : 99). Demikian pula Islam juga mengakui eksistensi agama-agama yang ada dan tidak menolak nilai-nilai ajarannya (lihat : QS.AIBaqarah : 62; QS. Al-An'am : 109; QS.Al-Haj : 40). Dan bahkan salah satu konsep yang ada gayutannya dengan pluralisme agama tersebut adalah konsep Islam tentang kesatuan nubuwab, mengakui para nabi dan rasul sebelum Muhammad (lihat: QS. Al-Baqarah : 136).

${ }^{13}$ lihat Prof.Dr. AZyumardi Azra, Konteks Berteologi di Indonesia : Pengalaman Islam, Paramadina, Jakarta 1999, hal 32. 